\title{
Pengurusan Mualaf di Malaysia: Kerjasama Dinamik Antara Agensi Kerajaan dan Bukan Kerajaan ${ }^{1}$
}

\author{
Siti Adibah Abu Bakar \\ Universiti Malaya, adibah_abk@yahoo.com \\ Siti Zubaidah Ismail \\ Universiti Malaya, szubaida@um.edu.my
}

\begin{abstract}
Abstrak
Pengurusan mualaf di Malaysia bukanlah sesuatu yang boleh dipandang enteng memandangkan terdapatnya peningkatan jumlah mualaf saban tahun. Di peringkat negeri, agensi kerajaan yang berautoriti dalam mentadbir hal ehwal mualaf adalah pihak Majlis atau Jabatan Agama Islam Negeri. Di samping itu, wujud juga beberapa agensi bukan kerajaan (NGO) yang turut ditubuhkan bagi menjalankan fungsi-fungsi berkaitan mualaf. Persoalannya, apakah fungsi atau peranan yang dimainkan oleh kedua-dua agensi di setiap negeri dan sejauh manakah penggemblengan tenaga disusun bagi menjalankannya. Objektif utama artikel ini adalah untuk mengkaji hubungan kerjasama yang terjalin antara kedua-dua agensi dalam memenuhi keperluan spiritual dan material mualaf di Malaysia. Metode yang digunakan dalam kajian ini adalah metode dokumentasi dan temu bual. Analisis data menunjukkan bahawa terdapat suatu jaringan kerjasama telah dibentuk antara agensi berkenaan sama ada pada sebahagian mahupun keseluruhan aspek; iaitu pada pengislaman dan pendaftaran, pendidikan, program bersama, ziarah dan kebajikan, dana serta permesyuaratan. Justeru, pada akhir artikel ini dicadangkan beberapa saranan bagi menambah baik kerjasama dan sistem pengurusan yang telah sedia ada.
\end{abstract}

Kata kunci: mualaf, pengurusan Islam, agensi Islam, NGO, dakwah

\section{Mualaf Management in Malaysia: Dynamic Collaboration Between Government and Non-Government Agencies}

\begin{abstract}
Management of converts in Malaysia is not something that can be taken lightly as there is an increase in the number of converts each year. At the state level, the authority to administer the affairs of the converts is the Islamic Religious Council or the Islamic Religious Department. In addition, there are also several non-governmental organizations (NGOs)
\end{abstract}

\footnotetext{
Artikel ini merupakan versi terkini kertas kerja yang telah dibentangkan di International Conference on Da'wah and Islamic Management (ICDAIM 2017) yang berlangsung pada 31 Oktober dan 1 November 2017, bertempat di Universiti Sains Islam Malaysia, Nilai, Negeri Sembilan.
} 
that are also set up to carry out the functions of dealing with the converts. The question is, what are the roles played by both agencies and NGOs in every state and how are they mobilized. The main objective of this article is to study the collaboration between the two agencies and $N G O s$ in meeting the spiritual and material needs of the converts in Malaysia. The method used in this study is the method of documentation and interview. The data shows that there is a network of co-operation has been established between the agencies concerned either in part or all aspects; namely the recruitment and registration, education, co-program, pilgrimage and charity, funds and meetings. At the end of this article, some recommendations have been proposed in order to improve existing collaboration and management system.

Keywords: converts, Islamic management, Islamic agency, NGO, da 'wah

\section{Pendahuluan}

Di peringkat negeri, seseorang yang baru memeluk agama Islam adalah dikenali sebagai mualaf atau saudara baru atau saudara kita. Manakala gelaran saudara Muslim pula diguna pakai di peringkat kebangsaan. Kepelbagaian istilah ini dan bahkan ketidakseragaman sistem pengurusan mualaf mengikut negeri adalah bertitik tolak daripada perundangan tertinggi di Malaysia yang meletakkan bidang kuasa pentadbiran mahupun perundangan agama Islam di bawah setiap negeri secara berasingan. ${ }^{2}$ Di setiap negeri, institusi agama yang berautoriti dalam menguruskan hal ehwal mualaf adalah Majlis Agama Islam Negeri (MAIN) atau Jabatan Agama Islam Negeri (JAIN). Kuasa tersebut berdasarkan kepada undang-undang pentadbiran agama Islam yang telah digubal, termasuklah kaedah atau peraturan lanjutan yang telah diadakan di bawahnya. Di samping agensi kerajaan tersebut, terdapat juga badan bukan kerajaan (NGO) yang turut ditubuhkan bagi menjalankan fungsi dakwah kepada golongan mualaf di Malaysia, sama ada beroperasi di peringkat negeri mahupun kebangsaan.

Jumlah mualaf di Malaysia menunjukkan peningkatan dari semasa ke semasa. Menurut statistik keluaran Jabatan Kemajuan Islam Malaysia (JAKIM), jumlah mualaf yang direkodkan dari tahun 2000 sehingga 2012 adalah seramai 106,747 orang. Meskipun begitu, di samping pertambahan bilangan tersebut, ia

2 Perkara 74 dan 80 (1), Perlembagaan Persekutuan. 
turut diselangi dengan isu-isu yang meruncing berkaitan mualaf bermula seawal mereka memeluk Islam sehinggalah selepas kematian mereka. Isu-isu yang melanda itu telah menimbulkan pelbagai polemik dalam kalangan masyarakat terhadap sejauhmana usaha atau tindakan yang telah diambil oleh badan berkuasa untuk menangani permasalahan kebajikan dan spiritual mualaf tersebut. Malangnya, di peringkat MAIN dan JAIN pula, wujudnya permasalahan kekurangan tenaga kerja untuk melayani segala keperluan mualaf yang semakin meningkat. ${ }^{3}$ Kesukaran mendapatkan penjawatan baru, ditambah pula dengan gerak kerja yang semakin meningkat, kekangan tersebut tidak mendapat perhatian sebilangan masyarakat yang cenderung menyangka pihak berwajib culas dalam menjalankan tanggungjawab mereka. Dalam masa yang sama, masyarakat sering beranggapan bahawa NGO seperti Pertubuhan Kebajikan Islam Malaysia (PERKIM), Persatuan Cina Muslim Malaysia (MACMA) dan lain-lain adalah lebih menonjol dan berperanan kepada mualaf berbanding pihak MAIN atau JAIN. ${ }^{4}$ Sedangkan kedua-dua badan kerajaan dan bukan kerajaan itu turut sama-sama mempunyai peranan tersendiri dalam mengurus tadbir perihal mualaf di Malaysia. Bahkan di peringkat NGO itu sendiri, sekalipun mereka mempunyai tenaga kerja yang ramai untuk menguruskan kebajikan dan pendidikan mualaf, namun mereka turut bergantung kepada pihak MAIN atau JAIN bagi mendapatkan sumber dana dalam menjalankan aktiviti yang telah disusun. ${ }^{5}$

Persoalannya di sini, apakah fungsi atau peranan yang dijalankan oleh MAIN atau JAIN dan juga NGO dalam menguruskan mualaf di Malaysia? Adakah terdapat satu jaringan

3 Berdasarkan temu bual yang dijalankan, jumlah staf bagi Bahagian atau Unit yang menguruskan mualaf di peringkat MAIN atau JAIN adalah tidak mencukupi. Misalnya di Sabah, hanya terdapat 10 orang staf bagi menguruskan purata tahunan mualaf seramai 1,800 orang. Di Kedah, seramai 4 orang staf bagi menguruskan purata tahunan mualaf seramai 176 orang dan begitu juga di Perlis yang hanya mempunyai 3 orang staf bagi menguruskan mualaf seramai 30 hingga 50 orang setahun.

4 Mohd Ridhuan Tee Abdullah, Cabaran Saudara Baru di Malaysia (Kuala Lumpur: Utusan Publications \& Distributors Sdn Bhd, 2012), 35.

5 "Pihak Berkuasa Agama dan NGO Perlu Bergandingan", laman sesawang Haluan, dikemaskini 8 September 2013, dicapai 2 Oktober 2017, http://www.haluan.org.my/v5/topik-pilihan/modal-insan/1912-pihak-berkuasaagama-dan-ngo-perlu-bergandingan. 
kerjasama secara rasmi dan penyelarasan aktiviti antara agensi kerajaan dan bukan kerajaan tersebut dalam menjalankan aktiviti pengislaman, pendidikan, kebajikan dan dakwah kepada golongan mualaf di peringkat negeri?

Oleh itu, artikel ini ditulis bagi menganalisis sejauhmana kerjasama yang telah dijalinkan antara pihak agensi kerajaan dan juga bukan kerajaan tersebut. Melalui penelitian terhadap peranan yang dijalankan oleh setiap pihak, suatu bentuk kerjasama secara bersistematik dapat dikenal pasti. Justeru, pada akhir nanti, suatu kesimpulan dan saranan penambahbaikan dapat dicadangkan kepada kedua-dua pihak kerajaan dan bukan kerajaan yang menguruskan mualaf di Malaysia.

\section{Keperluan Mualaf di Malaysia}

Kamus Dewan Edisi Keempat mendefinisikan keperluan sebagai sesuatu yang diperlukan, keharusan, kemestian; hajat, kehendak, maksud serta tujuan. Bagi golongan mualaf di Malaysia, terdapat lima keperluan utama yang seharusnya dipenuhi dan diuruskan oleh pihak yang bertanggungjawab terhadapnya; iaitu identiti, pendidikan dan bimbingan agama, kewangan dan kebajikan, dakwah dan kaunseling serta perundangan.

Pertama, identiti seseorang mualaf di Malaysia tidaklah boleh diremehkan memandangkan penduduk di negara ini terdiri daripada masyarakat majmuk berbilang bangsa dan agama. Identiti yang dimaksudkan termasuklah mendapatkan nama yang sesuai dan perolehan kad atau sijil pemelukan Islam yang sah setelah proses pengislaman dan pendaftaran. Bagi mualaf yang ingin mengekalkan nama asal mereka untuk tujuan pengekalan identiti bangsa seharusnya tidak menjadi halangan selagi nama tersebut mempunyai makna yang baik. ${ }^{6}$ Walhal, sekiranya mualaf tersebut ingin menambahkan nama Islam di hadapan nama asal mereka, hal ini adalah lebih digalakkan supaya dapat memberikan identiti yang berbeza setelah mereka menganut agama yang baru. Selain itu, perolehan kad atau sijil perakuan pemelukan Islam juga dapat menjadi bukti muktamad apabila timbulnya sebarang pertikaian

6 Adam Corrie, Ada Iman, Baru Syok, Ada Fight (Selangor: Mustread Sdn. Bhd., 2015), 119. 
terhadap status agama mualaf tersebut sama ada semasa mereka masih hidup atau selepas meninggal dunia. ${ }^{7}$

Kedua, pendidikan dan bimbingan agama juga amat diperlukan oleh seseorang mualaf bagi berpindah daripada formal conversion kepada practical conversion. ${ }^{8}$ Pendidikan dan bimbingan ini boleh diperolehi melalui penglibatan dalam kelaskelas yang disediakan sama ada oleh pihak MAIN atau JAIN atau NGO. Isi kandungan dan kaedah penyampaian pengajaran tersebut juga hendaklah bersesuaian dengan tahap kefahaman mualaf selaku seorang yang baru berjinak-jinak untuk mengenali Islam. Antara silibus penting sebagai pendedahan sebelum beranjak kepada bidang yang lebih mendalam adalah seperti ilmu fardu ain; tauhid, ibadah, akhlak, sirah dan pengajian al-Quran. ${ }^{9}$ Penyediaan modul atau buku teks dalam bahasa ibunda mualaf juga secara tidak langsung dapat memudahkan lagi mereka menguasai ilmu yang disampaikan. Bahkan, tidak hanya terhenti kepada pembelajaran di kelas-kelas, bimbingan seharian oleh mereka yang hampir dengan mualaf tersebut seperti pasangan Muslim dan jiran tetangga juga dapat membantu mereka memahami Islam dengan lebih berkesan lagi. ${ }^{10}$

Ketiga, setelah menganut agama Islam, kebanyakan mualaf akan terdedah kepada krisis kehidupan dan kewangan rentetan dihalau keluarga, dibuang kerja, dipulau oleh rakan dan sebagainya. Dengan itu, bantuan kewangan dan bukan wang amatlah diperlukan bagi meneruskan kelangsungan hidup mereka. Bantuan kewangan boleh disalurkan melalui pemberian wang sagu hati pemelukan Islam dan elaun kehadiran ke kelas atau program

7 Siti Zaleha Ibrahim, Nur Sarah Tajul Urus dan Mohd Faisal Mohamed, "Pertukaran Agama dan Kesannya Terhadap Komuniti: Satu Sorotan Terhadap Kes-kes Murtad dan Masuk Islam di Malaysia," Jurnal Sains Sosial dan Kemanusiaan 3 (2016), 212.

8 Azarudin Awang dan Khadijah Mohd Khambali@ Hambali, "Faktor Pemelukan Agama Islam: Kajian Terhadap Komuniti Saudara Muslim Cina di Negeri Terengganu," Jurnal Pusat Penataran Ilmu dan Bahasa 22 (2015), 38.

9 Zainab Ismail, Norabidah Pozi dan Wan Ibrahim Wan Ahmad, "Tahap Pengetahuan Agama Saudara Baru di Pusat Bimbingan Islam Saudara Baru Sultan Abdul Halim Mu'adzam Shah, Kedah Darul Aman," dalam Isu-Isu Pengurusan Saudara Muslim, ed. Razaleigh Muhamat @ Kawangit (Bangi: Penerbit Universiti Kebangsaan Malaysia, 2015), 91-93.

10 Ikhwan Ng, Dengan Lafaz Dua Kalimah Syahadah (Selangor: Mustread Sdn. Bhd., 2013), 64. 
yang dianjurkan sebagai dorongan. Manakala, bagi bantuan bukan wang pula boleh diberikan dalam bentuk makanan keperluan asas, pakaian, tempat perlindungan, bantuan perubatan, pendidikan dan banyak lagi. Sebagai asnaf yang layak menerima zakat, kebajikan dan hak mualaf seharusnya terbela melalui sistem agihan zakat yang efisien. Sekalipun beberapa negeri telah menetapkan had tempoh panggilan mualaf bagi memudahkan pengurusan pendidikan dan kebajikan mualaf berkenaan, namun penentuan tersebut hendaklah dilakukan bersama wujudnya suatu pelan perancangan jangka masa panjang bagi pembangunan spiritual dan material mualaf itu sendiri. ${ }^{11}$

Keempat, bagi mengetuk pintu hati mualaf yang masih belum kembali kepada fitrah atau masih lagi goyah lantaran cabaran dan tekanan hidup yang menghimpit, aktiviti dakwah dan kaunseling anjuran pihak berwajib juga amat diperlukan. Dakwah secara berhikmah dapat dilakukan melalui metode tinjauan (follow up) secara berkala sama ada dengan berziarah ke rumah mualaf atau menelefon mereka bagi mengetahui keadaan semasa yang dihadapi. ${ }^{12}$ Selain itu, penganjuran program-program dua hala yang dapat membina tautan ukhuwah sesama mualaf juga dapat menguatkan lagi keyakinan mereka untuk berpegang teguh kepada Islam. ${ }^{13}$ Sebagai platform meluahkan perasaan dan menyelesaikan kekusutan yang dihadapi, metode kaunseling juga dapat diadakan sama ada secara formal ataupun tidak. Bahkan, kaunseling didapati dapat menyelesaikan kebanyakan masalah mualaf yang ingin meninggalkan agama Islam. ${ }^{14}$

Akhir sekali yang kelima, perundangan yang lengkap juga amat diperlukan oleh seseorang mualaf. Peruntukan pemelukan

11 Aidit Ghazali dan Zulkifli Abd Hamid, "Program Bantuan Kepada Mualaf," dalam Pembangunan Dakwah Mualaf, ed. Rugayah Hj Tibek, Fariza Md. Sham dan Muhammad Hilmi Jalil (Bangi: Institut Islam Hadhari Universiti Kebangsaan Malaysia, 2014), 141-142.

12 Mohd Ridhuan Tee Abdullah, Cabaran Saudara Baru di Malaysia, 39.

13 Anuar Puteh, Razaleigh Muhamat @ Kawangit dan Rosmani Hussin, "Pelaksanaan Kurikulum Bimbingan Saudara Baru di Jabatan Hal Ehwal Agama Islam Kelantan," dalam Isu-Isu Pengurusan Saudara Muslim, ed. Razaleigh Muhamat@ Kawangit (Bangi: Penerbit Universiti Kebangsaan Malaysia, 2015), 164.

14 Nor Ashikin Md Nasir dan Siti Zubaidah Ismail, "Keluar Agama Islam di Malaysia: Permasalahan dari Sudut Undang-Undang," Jurnal of Shariah Law Research 1, no.1 (2016), 152. 
Islam yang terdapat di dalam Undang-Undang Pentadbiran Agama Islam Negeri dan juga Kaedah atau Peraturan yang diwujudkan di bawahnya dapat dirujuk untuk dijadikan panduan dalam mentadbir urus perihal mualaf di setiap negeri di Malaysia. Meskipun begitu, masih terdapat beberapa kelompangan terhadap perundangan bagi mualaf di Malaysia. Antaranya berkaitan dengan bidang kuasa mahkamah dalam soal penentuan status agama mualaf terutamanya selepas kematian mereka dan peruntukan mengenai keluar dari agama Islam. ${ }^{15}$ Bahkan, isu yang lebih kritikal lagi apabila terdapat konflik perundangan dalam soal pembubaran perkahwinan terdahulu mualaf bersama pasangan bukan Islam, hak penjagaan anak dan penentuan status agama anak mualaf tersebut. $^{16}$

Keperluan-keperluan mualaf di atas adalah berada di bawah tanggungan agensi-agensi terlibat di peringkat negeri. Bahagian seterusnya akan merungkai peranan yang dimainkan oleh pihakpihak agensi berkenaan bagi memenuhi keperluan tersebut.

\section{Peranan Agensi Kerajaan dan Bukan Kerajaan dalam Pengurusan Mualaf di Malaysia}

Badan kerajaan yang berautoriti dalam menguruskan mualaf di Malaysia adalah MAIN atau JAIN. ${ }^{17}$ Di sesetengah negeri, bahagian atau unit khusus bagi mentadbir hal ehwal mualaf adalah diletakkan sepenuhnya di bawah kelolaan MAIN seperti di Pahang. Manakala bagi negeri yang meletakkan sepenuhnya di bawah JAIN pula adalah seperti di Pulau Pinang dan Wilayah Persekutuan. Selain itu, terdapat juga negeri yang kedua-dua MAIN dan JAIN saling mempunyai tugas khusus untuk mualaf di negeri berkenaan, seperti yang berlaku di Kedah, Kelantan dan Terengganu. Meskipun mempunyai nama bahagian atau unit yang

15 Zanariah Dimon dan Zaini Yusnita Mat Jusoh, "Pengesahan Status Agama di Mahkamah Syariah: Satu Sorotan," (Prosiding Persidangan Penyelidikan dan Inovasi Antarabangsa Pertama 2014 (INSAN2014), Kuala Lumpur, 17-18 November 2014), 65.

16 Zaini Nasohah, Abdel Wadoud Moustafa Moursi Elseodi dan Mohd Izhar Ariff Mohd Kashim, "Status Agama Anak Bagi Ibubapa yang Memeluk Agama Islam di Malaysia," Jurnal Syariah (2010), 440-447.

17 Raja Dr. Nazrin Shah, Titah DiRaja Kongres Majlis Agama Islam Seluruh Malaysia Kali Pertama (Putrajaya: Jabatan Kemajuan Islam Malaysia (JAKIM), 2011), 4. 
berbeza di setiap negeri seperti Unit Ukhuwah, Unit Saudara Kita dan sebagainya, namun tugas atau fungsi yang dijalankan oleh MAIN atau JAIN tersebut bagi mentadbir urus mualaf di peringkat negeri adalah sama pada kebanyakannya. Dalam menjalankan peranan tersebut, boleh dikatakan semua negeri di Malaysia menggunakan wang zakat asnaf mualaf sebagai sumber dana mereka. ${ }^{18}$

Selain agensi kerajaan, Badan Bukan Kerajaan (NGO) juga turut memainkan peranan yang besar di peringkat negeri. Antaranya, Pertubuhan Kebajikan Islam Malaysia (PERKIM), Persatuan Cina Muslim Malaysia (MACMA), Kongres India Muslim Malaysia (KIMMA), Islamic Outreach Angkatan Belia Islam Malaysia (IOA) dan banyak lagi. Bagi melicinkan lagi pentadbiran, NGO-NGO tersebut turut beroperasi di peringkat pusat, bahagian dan cawangan atau daerah. Di samping mempunyai dana sendiri melalui penubuhan koperasi dan lainlain, NGO tersebut turut bergantung kepada agensi kerajaan bagi mendapatkan sumber dana dalam menjayakan sebarang aktiviti. Malah di beberapa negeri di Malaysia, peruntukan dana kepada NGO telah diberikan secara konsisten melalui bajet tahunan MAIN ataupun JAIN.

Bagi menjelaskan secara terperinci berhubung peranan agensi-agensi tersebut, pengelasan perbincangan akan dibuat mengikut beberapa aspek; iaitu aspek perundangan dan polisi, pengislaman dan pendaftaran, pendidikan, kewangan dan kebajikan, dakwah saudara baru dan akhir sekali pengurusan selepas kematian mualaf.

\section{Aspek Perundangan dan Polisi}

Sebagai institusi agama Islam yang terutama di peringkat negeri selepas Ketua Agama Islam, MAIN berperanan penuh untuk menggubal dasar-dasar berkaitan dengan pentadbiran agama Islam. Hal ini termasuklah perundangan mualaf yang diperuntukkan di dalam Enakmen Pentadbiran Agama Islam

18 Tuan Sakaria Samela, "Tadbir Urus Saudara Baru: Antara Santunan dan Terpaksa," (Kursus Tadbir Urus Saudara Baru, Jabatan Agama Islam Wilayah Persekutuan (JAWI), 26-27 November 2016). 
Negeri mahupun Kaedah atau Peraturan di bawahnya. ${ }^{19}$ Sekalipun semua negeri di Malaysia telah pun mempunyai peruntukan pemelukan Islam dalam Enakmen, namun hanya empat negeri sahaja yang telah pun mempunyai perincian peruntukan berkenaan dalam bentuk Kaedah atau Peraturan Pendaftaran, Penjagaan dan Pengajaran Mualaf. $^{20}$ Perundangan subsidiari tersebut adalah digubal atas tindakan permulaan oleh pihak pentadbir mualaf di MAIN atau JAIN sebelum disemak dan diluluskan oleh Ketua Agama Islam Negeri. Cetusan perundangan subsidiari daripada pihak pentadbir adalah disebabkan mereka lebih terdedah kepada perubahan isu dan kehendak semasa mualaf yang diuruskan. Begitu juga apabila timbul kes-kes bersangkutan mualaf di mahkamah, pihak pentadbir mualaf di MAIN atau JAIN akan terlibat sama ada sebagai pihak yang mewakili atau pihak lawan.

\section{Pengislaman dan Pendaftaran}

Pengislaman adalah satu proses yang berbeza dengan pendaftaran. Pengislaman melibatkan proses melafazkan syahadah dengan disaksikan oleh dua orang lelaki mukalaf dan ia boleh dilakukan di mana-mana, pada bila-bila masa dan dikendalikan oleh sesiapa sahaja termasuklah pihak MAIN atau JAIN, sukarelawan NGO mahupun imam atau nazir masjid. Manakala bagi pendaftaran pula, ia hanya boleh berlaku di pejabat MAIN atau JAIN pada waktu bekerja dan tertakluk kepada kelulusan Pendaftar yang dilantik menurut undang-undang sahaja. Proses pendaftaran akan berlaku atas permohonan mualaf itu sendiri dan sekiranya semua kehendak dokumentasi dipenuhi. Pendaftaran adalah kesinambungan kepada proses pengislaman seseorang mualaf, yang mana selepas selesai sahaja proses pendaftaran, maka mualaf itu akan diberikan sijil atau kad perakuan memeluk agama Islam.

19 Muhammad Haniff Baderun dan Zuliza Mohd Kusrin, "Fungsi dan Bidang Kuasa Majlis Agama Islam", laman sesawang Universiti Kebangsaan Malaysia, dicapai 15 September 2017, http://ukmsyariah.org/terbitan/wpcontent/uploads/2015/09/15-Muhammad-Haniff-Baderun.pdf, 188.

20 Negeri-negeri tersebut adalah Selangor, Pulau Pinang, Kedah dan Wilayah Persekutuan. 
Sijil atau kad tersebut menjadi satu identiti sah kepada mualaf dan juga sebagai bukti muktamad di mahkamah. ${ }^{21}$

\section{Pendidikan}

Bagi memenuhi keperluan spiritual mualaf, pihak MAIN dan JAIN juga menguruskan pendidikan mualaf melalui kelas-kelas bimbingan, kursus dan bengkel yang dianjurkan. Pada peringkat permulaan selepas mualaf itu masuk Islam, kebanyakan negeri mengadakan kursus pengenalan kepada agama Islam sekurangkurangnya selama tiga hingga lima hari dan bermalam. Kursus seumpama ini diadakan sebagai satu platform supaya mualaf mendapatkan pendedahan awal terhadap perkara-perkara asas dalam Islam sama ada dalam bentuk teori mahupun praktikal seperti perkara tauhid, ibadah solat, cara mandi wajib dan lain-lain lagi. Selain dapat mengikat mualaf yang masuk Islam atas kepentingan tertentu seperti perkahwinan dan sebagainya, ia turut menarik minat mualaf untuk terus mendalami agama Islam. ${ }^{22}$

Bagi pendidikan berkala secara harian mahupun mingguan, pihak MAIN atau JAIN dan juga NGO telah memainkan peranan bagi mengadakan kelas-kelas bimbingan fardu ain kepada mualaf. Terdapat perbezaan di antara negeri terhadap pelaksanaan kelas tersebut sama ada dari segi kekerapan, hari dan waktu, bilangan kelas dan tenaga pengajar, bahasa pengantar serta tempat belajar. Sekalipun silibus atau modul yang diguna pakai juga berlainan antara negeri-negeri, namun kesemua negeri menekankan pengajaran dalam perkara asas Islam termasuklah pengajian alQuran, akidah, fiqah, akhlak dan sirah. Di peringkat NGO, kelaskelas yang diadakan kebanyakannya menjadikan bahasa ibunda mualaf sebagai bahasa pengantar seperti Bahasa Cina, Bahasa Siam dan sebagainya. Bagi mualaf yang mempunyai kekangan untuk mengikuti jadual kelas yang disusun di peringkat MAIN atau JAIN, NGO turut menyediakan kelas persendirian kepada

21 Seksyen 107-112, Enakmen Petadbiran Agama Islam (Negeri Selangor) 2003; Bahagian III dan IV, Peraturan-peraturan Pendaftaran, Penjagaan dan Pengajaran bagi Muallaf (Negeri Selangor) 2009.

22 Ahmad Taufik Hamdan (Penolong Pegawai Hal Ehwal Islam, Jabatan Hal Ehwal Agama Islam Negeri Sembilan) dalam temu bual dengan penulis, 30 November 2016. 
mualaf yang berhajat dengan waktu yang fleksibel. ${ }^{23}$ Di samping itu, pihak MAIN atau JAIN dan NGO turut menitikberatkan pendidikan fardu kifayah kepada mualaf. Program-program dakwah dan ukhuwah sempena hari-hari kebesaran Islam yang bersifat santai, terbuka dan menarik menjadi acara tahunan mualaf. Bengkel-bengkel kemahiran seperti jahitan dan kewangan bersama institusi perbankan turut dianjurkan bagi membekalkan mualaf dengan ilmu kelangsungan hidup pada masa hadapan. ${ }^{24}$

Di Selangor, satu pelan strategik atau model sistem pendidikan telah disusun bagi memastikan mualaf di negeri Selangor dapat menguasai ajaran agama Islam dalam tempoh lima tahun, bersesuaian dengan had tempoh gelaran mualaf sepertimana yang telah digazetkan. Bahkan, kehadiran ke kelas turut menjadi salah satu syarat penerimaan bantuan yang disediakan kepada mualaf. Syarat seumpama ini bukanlah untuk tujuan menyusahkan, malah ia masih tertakluk atas budi bicara pihak pengurus mualaf di negeri berkenaan. ${ }^{25}$

\section{Kewangan dan Kebajikan}

Melalui dana zakat asnaf mualaf, penyaluran bantuan kewangan dan kebajikan mualaf di setiap negeri turut disediakan oleh MAIN atau JAIN. Bantuan kewangan tersebut termasuklah pemberian wang sagu hati atau insentif pemelukan Islam bagi menarik dan menjinakkan hati saudara baru di samping meringankan tekanan yang dihadapi semasa fasa permulaan masuk Islam. Meskipun diberikan dalam jumlah yang berbeza di antara negeri, terdapat juga negeri yang tidak menyediakan peruntukan wang seumpama ini seperti di Sarawak. Justifikasi tiada pelaksanaan sebegitu di Sarawak adalah kerana bantuan bagi mualaf di negeri berkenaan diberikan mengikut keperluan dan atas permohonan mualaf itu sendiri. ${ }^{26}$ Selain itu, boleh dikatakan hampir kesemua negeri di

23 Johari Abdullah (Pengerusi, MACMA Kelantan) dalam temu bual dengan penulis, 7 Ogos 2017.

24 Taufik Tee Abdullah (Pegawai Jabatan Hal Ehwal Agama Islam Kelantan) dalam temu bual dengan penulis, 3 Ogos 2017.

25 Suhaimi Ismail (Pengurus, Bahagian Pembagunan Muallaf Majlis Agama Islam Selangor) dalam temu bual dengan penulis, 29 November 2016.

${ }^{26}$ Madihi Jamali (Ketua Unit Kemajuan Saudara Kita, Bahagian Dakwah, Jabatan Agama Islam Sarawak) dalam temu bual dengan penulis, 10 Januari 2017. 
Malaysia kecuali Sarawak turut menyediakan elaun kehadiran ke kelas bimbingan agama anjuran MAIN atau JAIN dengan jumlah dan kaedah penyampaian yang berbeza. Elaun tersebut diberikan sebagai ganti duit minyak, makan minum dan kerana hilangnya mata pencarian mualaf pada hari kehadirannya ke kelas tersebut. ${ }^{27}$

Di samping bantuan berbentuk kewangan, kebajikan mualaf turut diuruskan oleh pihak MAIN atau JAIN dan NGO melalui bantuan perlindungan di rumah penempatan sementara, bantuan pendidikan dengan menanggung kos pengajian mualaf di institusiinstitusi terpilih, bantuan kos atau alat perubatan, bantuan perkahwinan dan banyak lagi. ${ }^{28}$ Dalam sesetengah keadaan seperti di Kelantan, pihak NGO akan membantu mualaf dalam membuat permohonan untuk mendapatkan bantuan di MAIN atau JAIN memandangkan kekurangan dana di peringkat NGO itu sendiri. Selain itu, program-program bantuan dan pembangunan sosioekonomi untuk masyarakat Islam dalam kalangan Orang Asli juga tidak diketepikan. ${ }^{29}$

\section{Dakwah Saudara Baru}

Aktiviti ziarah ke rumah dan hospital sama ada secara berkala atau bermusim telah disusun di sebahagian negeri bagi meninjau keadaan semasa mualaf di luar kelas dan program rasmi yang diadakan. Di samping bertukar cerita dan menyelami kisah kehidupan keluarga mualaf, ziarah tersebut turut dilaksanakan dengan membawa bersama sumbangan barangan keperluan asas untuk diberikan kepada pihak mualaf. Aktiviti ziarah saudara baru seumpama ini seharusnya dilaksanakan di semua negeri kerana ia menjadi nadi dakwah dalam menunjukkan keprihatinan masyarakat Islam kepada golongan mualaf di seluruh pelosok negeri. $^{30}$

27 Suhaimi Ismail (Pengurus, Bahagian Pembagunan Muallaf Majlis Agama Islam Selangor) dalam temu bual dengan penulis, 29 November 2016.

28 Azman Abdul Rahman, et al., "Skim Bantuan Zakat Asnaf Mualaf: Satu Analisis Kontemporari," Jurnal Pengurusan dan Penyelidikan Fatwa 6 (2015), 173.

29 Abdul Khalid Ahmad (Pegawai Islamic Outreach ABIM Center Kelantan) dalam temu bual dengan penulis, 7 Ogos 2017.

30 Azman Abdul Rahman, et al., "Persepsi Mualaf Terhadap Pengisian Pengislaman dan Program Pembangunan Mualaf: Kajian di Negeri Sembilan," Jurnal Pengurusan dan Penyelidikan Fatwa 6 (2015), 144. 
Selain aktiviti ziarah, khidmat rundingcara dan kaunseling sama ada secara formal atau tidak formal juga turut dilaksanakan di peringkat MAIN atau JAIN dan NGO. Menurut amalan di setiap negeri, rundingcara dan penasihatan adalah satu kemestian kepada mualaf yang mengalami masalah untuk meninggalkan agama Islam. Pendekatan yang diambil adalah dengan mengenal pasti punca masalah dan cuba membantu dari aspek yang menjadi ancaman kepada tergugatnya iman mereka seperti krisis kewangan, penceraian dan sebagainya. Elemen penerimaan qada' dan qadar serta menerapkan kesedaran dalam diri mualaf banyak diaplikasikan dalam sesi rundingcara tersebut. ${ }^{31}$

Jika diperhatikan kepada misi dan visi penubuhan sesebuah NGO, selain bagi tujuan aktiviti dakwah, kebanyakan NGO juga meletakkan penyebaran maklumat-maklumat Islam yang benar sebagai salah satu objektifnya. Bagi tujuan itu, penerbitan bahan bacaan secara bercetak mahupun elektronik dalam pelbagai bahasa penyampaian turut dilaksanakan. Buku, majalah, akhbar, makalah dan risalah turut diedarkan secara percuma kepada golongan mualaf dan orang awam. Hal ini secara tidak langsung dapat memperkenalkan keindahan Islam di samping menangkis tohmahan dan prejudis terhadap ajaran Islam. ${ }^{32}$

\section{Pengurusan Selepas Kematian Mualaf}

Bukan sahaja pengurusan semasa hidup, bahkan selepas kematian seseorang mualaf itu juga masih di bawah pengurusan pihak MAIN atau JAIN. Peranan tersebut termasuklah bagi memastikan supaya pengebumian mualaf dilakukan mengikut cara Islam. Selain itu, bagi kes-kes mualaf yang merahsiakan keislaman sepanjang hidupnya, pihak MAIN atau JAIN juga bertanggungjawab untuk memberitahu dan menjelaskan status

31 Salasilah Hanin Hamjah, "Bimbingan Spiritual Menurut Al-Ghazali dan Hubungannya dengan Keberkesanan Kaunseling: Satu Kajian di Pusat Kaunseling Majlis Agama Islam Negeri Sembilan (PK MAINS)," Islamiyyat 32 (2010), 52; Zakaria Noh, "Peranan Pertubuhan Kebajikan Islam Malaysia (PERKIM) dalam Pembinaan Keagamaan Mualaf di Malaysia," (tesis kedoktoran, Universitas Islam Negeri Sultan Syarif Kasim Riau, 2010), 29.

32 Nur Hieadayah Abdul Rahim dan Idris Zakaria, "Dakwah PERKIM kepada Etnik Cina di Malaysia," Islamiyyat 36, no. 1 (2014), 65. 
agama mualaf tersebut kepada keluarganya yang bukan Islam sekiranya timbul sebarang pertikaian atau kekeliruan. ${ }^{33}$

Melalui perbincangan di atas, kita dapat lihat bahawa peranan yang dimainkan oleh pihak agensi kerajaan dan bukan kerajaan adalah meliputi seluruh aspek keperluan pasca konversi mualaf. Pendekatan yang diambil oleh kedua-dua agensi tersebut dalam memainkan peranan-peranan itu juga mempunyai persamaan pada kebanyakan aspek. Dengan itu, pada bahagian selepas ini akan mengkaji tahap kerjasama yang terjalin antara agensi berkenaan dalam menggembleng tenaga bagi menguruskan mualaf di peringkat negeri di Malaysia.

\section{Kerjasama Antara Agensi Kerajaan dan Bukan Kerajaan}

Melalui temu bual bersama pegawai mualaf di MAIN atau JAIN di seluruh negeri di Malaysia, serta beberapa buah NGO, data dan maklumat mengenai kerjasama yang wujud antara MAIN atau JAIN dengan pihak NGO telah dikumpulkan. Terdapat lima kelas aspek kerjasama yang akan dihuraikan; iaitu pengislaman dan pendaftaran, pendidikan, program dan aktiviti, kebajikan dan dana serta mesyuarat atau dialog bersama.

\section{Pengislaman dan Pendaftaran}

Sebagai badan bukan kerajaan, NGO lebih bebas dalam pergerakan dakwah dan seruan kepada agama Islam. Hal ini apabila aktiviti dan kegiatan yang dilakukan tidak hanya terbatas kepada orang Islam sahaja, sebaliknya turut melibatkan orang bukan Islam di Malaysia. Maka tidak hairanlah apabila ramai mualaf yang mendatangi pihak NGO dahulu sebelum ke Pejabat Agama bagi menyatakan hasrat mereka untuk masuk Islam. Menjadi amalan di semua negeri kecuali Perlis, pengislaman di peringkat NGO akan terus didaftarkan sekiranya menepati kehendak dokumentasi yang digariskan. Manakala di Perlis, sekalipun pengislaman telah diadakan lebih awal di peringkat NGO, seseorang yang ingin masuk Islam di Perlis hendaklah

33 Mohd Leow Abdullah (Penolong Setiausaha, Bahagian Balai Islam Majlis Agama Islam Melaka) dalam temu bual dengan penulis, 14 Disember 2016. 
melafazkan semula syahadahnya di JAIN sebelum boleh didaftarkan bagi tujuan rekod sah. ${ }^{34}$

Di Selangor pula, satu kerjasama rasmi telah dibentuk antara Majlis Agama Islam Selangor (MAIS) dengan lima buah NGO terpilih di negeri itu; iaitu Pertubuhan Kebajikan Islam Malaysia (PERKIM), Persatuan Cina Muslim Malaysia (MACMA), Islamic Outreach Angkatan Belia Islam Malaysia (IOA), Hidayah Centre Foundation (HCF) dan Multiracial Reverted Muslim (MRM). NGO-NGO tersebut telah dijadikan pusat pendaftaran mualaf, yang mana mereka telah diberikan panduan menyeluruh untuk menjalankan proses pengislaman termasuklah penerangan sebelum majlis pengislaman dan pembacaan deklarasi selepasnya. Borang dan dokumentasi yang telah lengkap akan dibawa ke ibu pejabat bagi tujuan pendaftaran. Bukan itu sahaja, malah sebarang rekod pengislaman, pendaftaran dan manfaat kebajikan yang diterima oleh mualaf berkenaan turut dikendalikan di pusat-pusat pendaftaran tersebut. Pemantapan proses pengislaman dan pendaftaran ini dilaksanakan bagi mengelakkan implikasi buruk yang mendatang berkaitan mualaf. ${ }^{35}$

\section{Pendidikan}

Seperti yang dijelaskan dalam bahagian sebelum ini, kedua-dua pihak MAIN atau JAIN dan NGO masing-masing telah mengadakan kelas pendidikan kepada mualaf di setiap negeri. Walau bagaimanapun, dalam menjayakannya, terdapat situasi di mana beberapa negeri memilih untuk bekerjasama dan begitu juga sebaliknya. Bagi negeri Selangor, Sarawak, Sabah, Pulau Pinang dan Kelantan, wujud satu kerjasama sama ada secara penyelarasan ataupun makluman. Sebagai contoh di Selangor, kelas yang diadakan di peringkat NGO telah diselaraskan dan turut dianggap sebagai salah satu kelas anjuran MAIS. Hal ini bermakna, mualaf boleh memilih untuk hadir ke mana-mana kelas yang bersesuaian dengan kehendak bahasa dan masa mereka. Selain saling berkongsi maklumat kehadiran mualaf ke kelas, pihak MAIN dan JAIN juga turut menjadi tempat rujukan NGO untuk mendapatkan

\footnotetext{
34 Fakhrurrazi Md Mahathir (Pendaftar Mualaf Negeri Perlis) dalam temu bual dengan penulis, 28 Disember 2016.

35 Suhaimi Ismail (Pengurus, Bahagian Pembagunan Muallaf Majlis Agama Islam Selangor) dalam temu bual dengan penulis, 29 November 2016.
} 
syor modul pendidikan yang sesuai bagi digunakan semasa pembelajaran. Tambahan pula di Kelantan, tenaga pengajar bagi kelas anjuran JAIN turut diambil dalam kalangan ahli NGO di negeri berkenaan. ${ }^{36}$ Manakala, bagi negeri lain seperti Perak, Terengganu, Negeri Sembilan dan Pahang, kelas pendidikan anjuran MAIN atau JAIN dan pihak NGO adalah saling tidak berhubungan. Masing-masing melaksanakan kelas tanpa pemantauan atau makluman secara langsung antara satu sama lain.

Selain itu, di Kedah dan Perlis pula, kelas pendidikan kepada mualaf di sana tidak dikendalikan oleh pihak JAIN, tetapi sepenuhnya dikelolakan oleh pihak NGO; iaitu PERKIM. Di Perlis, sekalipun kelas bagi mualaf yang diadakan di pusat aktiviti PERKIM pada setiap hari bekerja adalah sepenuhnya di bawah kendalian pihak PERKIM, namun pihak JAIN turut terlibat untuk memantau kehadiran dan pengurusan modul pembelajaran, pemberian elaun kehadiran pelajar serta lantikan tenaga pengajar termasuklah elaun mereka. Namun begitu, kerjasama seumpama itu tidak berlaku di Kedah. Mualaf di Kedah boleh mendapatkan pendidikan secara formal di Pusat Bimbingan Islam Sultan Abdul Halim Mu'adzam Shah (PUSBA), Sungai Petani selain menyertai kelas anjuran PERKIM. ${ }^{37}$

\section{Program dan Aktiviti}

Program yang dimaksudkan di sini termasuklah program dakwah dan ukhuwah. Manakala aktiviti pula melibatkan ziarah dan kaunseling. Boleh dikatakan di semua negeri di Malaysia, satu jaringan kerjasama telah dijalinkan antara pihak MAIN atau JAIN dengan pihak NGO untuk mengendalikan program-program kepada mualaf. Sebagai contoh di Johor, pihak NGO telah dilibatkan bersama dalam anjuran Kursus Fasa Pemantapan Saudara Kita, Program Sehari "Mari Kenali Islam", Dialog bersama Tokoh Mualaf, program keluarga angkat dan banyak

36 Rosmadi Ramli (Penolong Pengarah, Unit Dakwah dan Ukhuwah, Bahagian Dakwah, Jabatan Hal Ehwal Agama Islam Kelantan) dalam temu bual dengan penulis, 3 Ogos 2017.

37 Mohd Naim Hj Ahmad (Pengarah, Bahagian Dakwah, Jabatan Agama Islam Kedah) dalam temu bual dengan penulis, 17 Januari 2017. 
lagi. ${ }^{38}$ Sekalipun terdapat program-program NGO yang tidak dianjurkan secara bersama dengan MAIN atau JAIN, ia dilaksanakan dengan pemantauan atau makluman kepada pihak MAIN atau JAIN bagi mendapatkan dana. Begitu juga dengan aktiviti ziarah, pihak NGO adalah lebih bergiat aktif dalam melaksanakannya di bawah pemantauan MAIN atau JAIN. Selain ziarah oleh pihak PERKIM di Perlis, di Melaka juga, satu Skuad Sukarelawan Balai Islam Majlis Agama Islam Melaka (MAIM) yang terdiri daripada kalangan ahli NGO telah ditubuhkan. Di samping menziarahi mualaf, antara tugasan utama skuad tersebut adalah untuk mengenal pasti tahap pendidikan, ekonomi, masalah keluarga, pergaulan dengan masyarakat sekeliling, penguasaan fardu ain dan sebagainya. Kekerapan ziarah tersebut adalah sebanyak lapan kali sebulan dan setiap kali ziarah selama tempoh dua jam akan dibayar elaun RM80. ${ }^{39}$

Walaupun begitu, bagi penganjuran program dan aktiviti di perkampungan Orang Asli seperti di Pahang atau di pedalaman Sarawak, terdapat juga situasi di mana tiada kerjasama mahupun makluman kepada pihak MAIN atau JAIN daripada pihak NGO. Hal ini menyebabkan berlakunya pertindihan aktiviti, ketidaksesuaian uslub dakwah yang digunakan dan bahkan apabila timbulnya sebarang masalah, pihak agensi kerajaan yang terpaksa pula menjernihkan kembali keadaan. ${ }^{40}$

\section{Kebajikan dan Dana}

Kebajikan kepada mualaf pada asasnya adalah bersumberkan wang zakat. Di peringkat NGO, selain mempunyai dana sendiri, mereka turut bergantung kepada peruntukan wang zakat yang diperoleh dari MAIN atau JAIN bagi melaksanakan aktiviti dan kebajikan mualaf. Di Terengganu, dana bagi program NGO di negeri tersebut hanya akan diberikan sekiranya program tersebut belum lagi dijalankan di peringkat MAIN dan setelah menepati

38 Mohd. Fauzi Bachok (Penolong Pengarah, Unit Ukhuwah, Bahagian Dakwah, Jabatan Agama Islam Negeri Johor) dalam temu bual dengan penulis, 5 Januari 2017.

39 Mohd Leow Abdullah (Penolong Setiausaha, Bahagian Balai Islam Majlis Agama Islam Melaka) dalam temu bual dengan penulis, 14 Disember 2016.

40 Madihi Jamali (Ketua Unit Kemajuan Saudara Kita, Bahagian Dakwah, Jabatan Agama Islam Sarawak) dalam temu bual dengan penulis, 10 Januari 2017. 
piawaian yang ditentukan. ${ }^{41}$ Manakala di Kelantan pula, pemberian dana kepada NGO adalah dibuat melalui peruntukan geran tahunan oleh MAIN secara konsisten. Walaupun begitu, sekiranya terdapat keperluan mendatang yang tidak mencukupi, permohonan dana masih boleh dibuat oleh pihak NGO. ${ }^{42}$

Selain peruntukan dana bagi menjalankan aktiviti dan program, NGO juga turut menjadi perantara kepada pihak MAIN atau JAIN dalam menyampaikan sumbangan dan bantuan kepada mualaf. Misalnya di Perak, mubaligh yang dilantik dan terdiri dalam kalangan ahli NGO akan mendapatkan bantuan bagi pihak mualaf di Baitulmal ataupun melalui 'wang pujuk' dari pihak JAIN. ${ }^{43}$

Di samping kebajikan berbentuk kewangan dan bantuan keperluan asas, bantuan berupa rumah perlindungan sementara juga turut dikelolakan sama ada di peringkat MAIN atau JAIN atau NGO dan ia menjadi manfaat bersama. Misalnya di Sabah, Rumah Kebajikan Saudara Kita di Likas adalah dikendalikan oleh pihak NGO; Persatuan Prihatin Sahabat Sabah bagi membolehkan mualaf yang bermasalah transit selama tiga bulan di sana sebelum menemukan rumah dan pekerjaan yang sesuai. Pembiayaan rumah tersebut adalah ditanggung oleh pihak JAIN, Jabatan Kemajuan Islam Malaysia (JAKIM) dan Pusat Zakat Sabah. ${ }^{44}$

\section{Mesyuarat dan Dialog Bersama}

Bagi melancarkan operasi kerjasama antara agensi kerajaan dan bukan kerajaan, beberapa negeri seperti Selangor, Sarawak, Melaka, Kedah, Sabah dan Kelantan telah mengambil pendekatan untuk mengadakan mesyuarat atau dialog bersama secara kerap mahupun terancang. Di Selangor contohnya, pihak MAIN akan

41 Abdul Halim Lim Abdul Rahman (Ketua Unit Dakwah Saudara Kita, Majlis Agama Islam dan Adat Melayu Terengganu) dalam temu bual dengan penulis, 4 Disember 2016.

42 Johari Abdullah (Pengerusi, MACMA Kelantan) dalam temu bual dengan penulis, 7 Ogos 2017.

43 Adibah Haji Mohamad Rifaie (Penolong Pengarah Kanan, Bahagian Dakwah, Jabatan Agama Islam Perak) dalam temu bual dengan penulis, 22 Disember 2016.

44 Aisah Ohdin (Penyelia Unit Ukhuwah, Bahagian Dakwah, Jabatan Hal Ehwal Agama Islam Negeri Sabah) dalam temu bual dengan penulis, 11 Januari 2017. 
mengadakan mesyuarat bersama pusat-pusat pendaftaran yang terdiri daripada kalangan NGO terpilih sekurang-kurangnya dua kali setahun, namun biasanya diadakan empat kali setahun seiring mesyuarat Jawatankuasa Hal Ehwal Mualaf Selangor dan sekiranya terdapat isu-isu baru yang timbul. Walaupun begitu, pada setiap awal tahun, pihak MAIN akan turun (roadshow) ke setiap pusat pendaftaran terlibat bagi menyemak semula gerak kerja dan menyampaikan maklumat. ${ }^{45}$

Di sesetengah negeri, sekalipun mesyuarat telah diadakan, wujud permasalahan dalam mencapai kesepakatan atau kerjasama antara pihak MAIN atau JAIN dengan pihak NGO. Hal ini seperti di Kelantan, apabila wujud rungutan dari pihak NGO di sana supaya mesyuarat yang dikendalikan oleh pihak MAIN bagi tujuan pembahagian kampung Orang Asli sepatutnya ditentukan dengan mengambil kira kekuatan setiap NGO yang terlibat seperti pengangkutan serta tenaga penggerak dakwah yang dimiliki. Malah, penyelarasan aktiviti dakwah kepada Orang Asli haruslah diutamakan berbanding pembahagian kawasan tersebut. ${ }^{46}$ Begitu juga yang berlaku di Negeri Sembilan, mesyuarat yang pernah diadakan antara pihak JAIN dengan NGO di sana bagi mengadakan kerjasama dalam pendidikan mualaf di negeri tersebut tidak berjaya mencapai kesepakatan. Bukan sahaja berpunca daripada perbezaan corak pemikiran, hal ini juga kerana tiada kebergantungan dana oleh pihak NGO berkenaan dengan pihak JAIN. $^{47}$

\section{Analisis}

Berdasarkan kepada perbincangan dalam bahagian sebelum ini, didapati bahawa, boleh dikatakan telah wujud satu jaringan kerjasama sama ada secara rasmi ataupun tidak antara pihak MAIN atau JAIN dengan pihak NGO di semua negeri di Malaysia. Kerjasama yang terjalin itu juga sama ada secara menyeluruh ataupun hanya pada sebahagian peranan sahaja. Bagi merumuskan

45 Suhaimi Ismail (Pengurus, Bahagian Pembagunan Muallaf Majlis Agama Islam Selangor) dalam temu bual dengan penulis, 29 November 2016.

46 Abdul Khalid Ahmad (Pegawai Islamic Outreach ABIM Center Kelantan) dalam temu bual dengan penulis, 7 Ogos 2017.

47 Ahmad Taufik Hamdan (Penolong Pegawai Hal Ehwal Islam, Jabatan Hal Ehwal Agama Islam Negeri Sembilan) dalam temu bual dengan penulis, 30 November 2016. 
perbincangan sebelum ini, hal ini boleh dirujuk kepada jadual di bawah.

Jadual 1: Kerjasama antara MAIN atau

JAIN dengan NGO Mualaf di Malaysia

\begin{tabular}{|c|c|c|c|c|c|c|}
\hline \multirow[b]{2}{*}{ Negeri } & \multicolumn{6}{|c|}{ Skop Kerjasama antara MAIN/JAIN dengan NGO } \\
\hline & 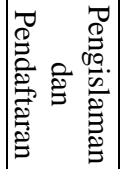 & 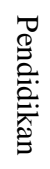 & 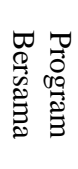 & 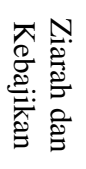 & Dana & Syura \\
\hline Selangor & $\sqrt{ }$ & $\sqrt{ }$ & $\sqrt{ }$ & $\sqrt{ }$ & $\sqrt{ }$ & $\sqrt{ }$ \\
\hline Wilayah Persekutuan & $\sqrt{ }$ & $\mathrm{O}$ & $\sqrt{ }$ & o & $\sqrt{ }$ & o \\
\hline Negeri Sembilan & $\sqrt{ }$ & $\mathrm{o}$ & $\sqrt{ }$ & o & $\sqrt{ }$ & $\mathrm{o}$ \\
\hline Melaka & $\sqrt{ }$ & o & $\sqrt{ }$ & $\sqrt{ }$ & $\sqrt{ }$ & $\sqrt{ }$ \\
\hline Johor & $\sqrt{ }$ & o & $\sqrt{ }$ & $\sqrt{ }$ & $\sqrt{ }$ & $\sqrt{ }$ \\
\hline Perak & $\sqrt{ }$ & $\mathrm{O}$ & $\sqrt{ }$ & $\sqrt{ }$ & $\sqrt{ }$ & 0 \\
\hline Pulau Pinang & $\sqrt{ }$ & $\sqrt{ }$ & $\sqrt{ }$ & $\sqrt{ }$ & $\sqrt{ }$ & 0 \\
\hline Kedah & $\sqrt{ }$ & $\mathrm{O}$ & $\sqrt{ }$ & $\mathrm{O}$ & $\sqrt{ }$ & $\sqrt{ }$ \\
\hline Perlis & $\sqrt{ }$ & $\sqrt{ }$ & $\sqrt{ }$ & o & $\sqrt{ }$ & o \\
\hline Pahang & $\sqrt{ }$ & $\mathrm{o}$ & $\sqrt{ }$ & $\sqrt{ }$ & $\sqrt{ }$ & $\sqrt{ }$ \\
\hline Terengganu & $\sqrt{ }$ & o & $\sqrt{ }$ & o & $\sqrt{ }$ & o \\
\hline Kelantan & $\sqrt{ }$ & $\sqrt{ }$ & $\sqrt{ }$ & $\sqrt{ }$ & $\sqrt{ }$ & $\sqrt{ }$ \\
\hline Sabah & $\sqrt{ }$ & $\sqrt{ }$ & $\sqrt{ }$ & $\sqrt{ }$ & $\sqrt{ }$ & $\sqrt{ }$ \\
\hline Sarawak & $\sqrt{ }$ & $\sqrt{ }$ & $\sqrt{ }$ & $\sqrt{ }$ & $\sqrt{ }$ & $\sqrt{ }$ \\
\hline
\end{tabular}

Nota: $\sqrt{ }$ - wujud kerjasama o - tiada kerjasama

Kerjasama yang terjalin antara badan kerajaan dan bukan kerajaan dalam pengislaman dan pendaftaran mualaf di Malaysia adalah satu kemestian. Hal ini seiring dengan perundangan dan polisi yang terpakai di negara ini yang membolehkan pengislaman berlaku dengan sesiapa yang mukalaf, di mana-mana dan pada bila-bila masa. Namun, bagi pendaftaran pengislaman itu telah ditetapkan kuasa khusus baginya, iaitu pada badan-badan kerajaan sahaja dan pastinya setelah prasyarat dokumentasi dipenuhi. Langkah kerjasama secara rasmi di Selangor dalam aspek ini adalah satu usaha yang bersistematik di samping dalam masa yang sama, dapat memberi kesedaran kepada NGO yang terlibat terhadap peri pentingnya prosedur majlis pengislaman yang harus dikendalikan. Penerangan yang berkesan dan majlis syahadah yang tulus akan secara tidak langsung menyemai fitrah ketuhanan di samping dapat memberikan pendedahan awal kepada mualaf 
tersebut akan obligasi dan hak mereka sebagai seorang Islam. Langkah seumpama ini dapat membantu mualaf mempersiapkan diri dalam menghadapi tekanan hidup yang mendatang dan bagi implikasi jangka masa panjang, supaya tiada lagi kes mualaf yang ingin kembali kepada agama asal mereka.

Selain penumpuan kepada aspek pengislaman dan pendaftaran mualaf bagi tujuan identiti, penggemburan ilmu dan penghayatan mualaf terhadap ajaran agama Islam juga tidak boleh dipandang enteng. Seharusnya setiap mualaf itu dipastikan supaya mendapat pendidikan dan bimbingan agama yang sewajarnya, sama ada dengan mengikuti kelas di peringkat MAIN atau JAIN atau NGO, atau bahkan secara persendirian di rumah kediaman sekalipun. Dengan itu, kerjasama antara badan kerajaan dan NGO dalam aspek penyediaan pendidikan kepada mualaf ini dilihat lebih menguntungkan apabila setiap mualaf itu dapat menyertai kelas-kelas pendidikan mengikut kesesuaian masa dan keselesaan mereka. Hal ini memandangkan, antara alasan mualaf apabila gagal menghadirkan diri ke kelas-kelas yang disediakan adalah kerana terikat dengan komitmen kerjaya dan keluarga masingmasing. Bukan sahaja penyusunan dan penyelarasan kelas-kelas yang banyak dan fleksibel, malah saling berkongsi maklumat antara pihak MAIN atau JAIN dan NGO seperti mengenai kehadiran ke kelas, modul atau silibus yang digunakan, penerimaan mualaf terhadap pengajaran dan sebagainya juga tidak kurang pentingnya supaya dapat dipastikan bahawa semua mualaf mendapat pendidikan yang sepatutnya tanpa ada seorang pun yang tercicir.

Begitu juga dengan pelaksanaan program-program dakwah dan ukhuwah di semua negeri di Malaysia, penggemblengan tenaga antara badan kerajaan dan bukan kerajaan dapat memudahkan penyaluran dana di samping memperbanyak aktiviti dan mengelakkan pengulangan atau pertindihan program yang diadakan. Dengan penglibatan pihak NGO yang kebanyakannya juga adalah merupakan saudara baru, secara tidak langsung dapat mencetuskan idea-idea yang bernas terhadap keperluan program yang sesuai untuk golongan mualaf. Seterusnya, ia dapat menarik lebih ramai penglibatan peserta mualaf ke dalam program-program yang dianjurkan. 
Seperti yang dimaklumi, agensi kerajaan dan bukan kerajaan masing-masing mempunyai kekuatan dan kelemahan yang tersendiri. Langkah kerjasama yang diambil oleh sebahagian negeri di Malaysia dalam aktiviti ziarah dan kebajikan mualaf didapati dapat meraikan kekuatan tenaga dan kepakaran yang dimiliki oleh pihak NGO di samping kekuatan dana yang dimiliki oleh pihak MAIN atau JAIN. Penubuhan sistem sokongan khas bagi menjalankan aktiviti tersebut seperti yang berlaku di Sarawak, Melaka dan Perak dilihat mampu menjalankan operasi follow up, ziarah dan kaunseling dengan lebih berkesan dan menyeluruh. Selain mengetahui keperluan mualaf melalui permohonan mereka di pejabat zakat, pengenalpastian dan keprihatinan terhadap masalah dan keperluan mendesak mualaf juga boleh diperolehi melalui lawatan secara berkala dan terancang. Penyaluran bantuan dan sumbangan dengan lebih efisien dapat meminimumkan pengabaian kebajikan mualaf di Malaysia.

Akhir sekali, bagi melicinkan pentadbiran kerjasama yang terjalin antara MAIN atau JAIN dan NGO, pewujudan medium perkongsian dan perbincangan iaitu melalui mesyuarat atau dialog bersama hendaklah diadakan di setiap negeri di Malaysia. Hal seumpama ini telah pun dilaksanakan di Selangor, Sarawak, Kelantan, Kedah, Sabah dan Pahang. Mesyuarat tersebut bukan sahaja menjadi platform penyelarasan dan laporan gerak kerja, malah ia dapat dimanfaatkan untuk berdiskusi dan mencari jalan penyelesaian bagi sebarang isu mualaf yang timbul.

\section{Saranan Dan Penutup}

Kesimpulannya, kerjasama antara agensi kerajaan dan bukan kerajaan dalam menguruskan mualaf di Malaysia wujud dalam bentuk dan aspek yang berbeza mengikut negeri. Meskipun perbezaan dan kelainan yang wujud itu adalah berdasarkan kepada keunikan dan situasi semasa di setiap negeri, namun usahasama antara badan-badan Islam di Malaysia tidaklah patut dipandang ringan. Kesatuan fikrah dan harakah sewajarnya diserlahkan melalui strategi pelaksanaan yang bersistematik dan efisien supaya dakwah yang ingin disampaikan dapat tersebar dengan lebih luas dan mantap. Dengan itu, bertepatan dengan penggubalan undangundang dan polisi bagi mualaf di Malaysia, satu jaringan 
kerjasama yang terancang dan menyeluruh haruslah dibentuk dalam mengurus tadbir perihal mualaf di setiap negeri. Sebagai pihak yang berautoriti, pihak MAIN atau JAIN hendaklah merangka satu pelan pengurusan komprehensif bagi menjelaskan misi pentadbiran mualaf di samping penyusunan keterlibatan sistem sokongan seperti NGO, masjid dan lain-lain lagi. Penyusunan tersebut dapat dilakukan dengan menilai kekuatan dan kelemahan yang wujud pada setiap pihak yang berkenaan. Justeru, dengan adanya satu sistem kerjasama yang dinamik dan tersusun di setiap negeri di Malaysia, khususnya dalam hal ehwal pengurusan mualaf, hal ini dapat meringankan beban yang ditanggung oleh pihak-pihak di samping melancarkan usaha dakwah yang dilaksanakan dan seterusnya mencapai matlamat yang dihasratkan.

\section{Rujukan}

Adam Corrie. Ada Iman, Baru Syok, Ada Fight. Selangor: Mustread Sdn. Bhd., 2015.

Aidit Ghazali dan Zulkifli Abd Hamid, "Program Bantuan kepada Mualaf," dalam Pembangunan Dakwah Mualaf, ed. Rugayah Hj Tibek, Fariza Md. Sham dan Muhammad Hilmi Jalil. Bangi: Institut Islam Hadhari Universiti Kebangsaan Malaysia, 2014.

Anuar Puteh, Razaleigh Muhamat @ Kawangit dan Rosmani Hussin. "Pelaksanaan Kurikulum Bimbingan Saudara Baru di Jabatan Hal Ehwal Agama Islam Kelantan," dalam Isu-Isu Pengurusan Saudara Muslim, ed. Razaleigh Muhamat @ Kawangit. Bangi: Penerbit Universiti Kebangsaan Malaysia, 2015.

Azarudin Awang dan Khadijah Mohd Khambali @ Hambali. "Faktor Pemelukan Agama Islam: Kajian Terhadap Komuniti Saudara Muslim Cina di Negeri Terengganu," Jurnal Pusat Penataran Ilmu dan Bahasa 22 (2015): 38.

Azman Abdul Rahman, et al.. "Skim Bantuan Zakat Asnaf Mualaf: Satu Analisis Kontemporari," Jurnal Pengurusan dan Penyelidikan Fatwa 6 (2015): 173.

Azman Abdul Rahman, et al., "Persepsi Mualaf Terhadap

Pengisian Pengislaman dan Program Pembangunan Mualaf: Kajian di Negeri Sembilan," Jurnal Pengurusan dan Penyelidikan Fatwa 6 (2015): 144. 
Enakmen Petadbiran Agama Islam (Negeri Selangor) 2003.

Ikhwan Ng, Dengan Lafaz Dua Kalimah Syahadah. Selangor: Mustread Sdn. Bhd., 2013.

Mohd Ridhuan Tee Abdullah. Cabaran Saudara Baru di Malaysia. Kuala Lumpur: Utusan Publications \& Distributors Sdn Bhd, 2012.

Muhammad Haniff Baderun dan Zuliza Mohd Kusrin. "Fungsi dan Bidang Kuasa Majlis Agama Islam", laman sesawang Universiti Kebangsaan Malaysia, dicapai 15 September 2017, http://ukmsyariah.org/terbitan/wp-content/uploads/2015/09/15Muhammad-Haniff-Baderun.pdf, 188.

Nor Ashikin Md Nasir dan Siti Zubaidah Ismail. "Keluar Agama Islam di Malaysia: Permasalahan dari Sudut Undang-Undang," Jurnal of Shariah Law Research 1, no.1 (2016): 152.

Nur Hieadayah Abdul Rahim dan Idris Zakaria. "Dakwah PERKIM kepada Etnik Cina di Malaysia," Islamiyyat 36, no. 1 (2014): 65.

Peraturan-peraturan Pendaftaran, Penjagaan dan Pengajaran bagi Muallaf (Negeri Selangor) 2009.

"Pihak Berkuasa Agama dan NGO Perlu Bergandingan", laman sesawang Haluan, dikemaskini 8 September 2013, dicapai 2 Oktober 2017, http://www.haluan.org.my/v5/topikpilihan/modal -insan/1912-pihak-berkuasa-agama-dan-ngoperlu-ber gandingan.

Raja Dr. Nazrin Shah. Titah DiRaja Kongres Majlis Agama Islam Seluruh Malaysia Kali Pertama. Putrajaya: Jabatan Kemajuan Islam Malaysia (JAKIM), 2011.

Salasilah Hanin Hamjah, "Bimbingan Spiritual Menurut AlGhazali dan Hubungannya dengan Keberkesanan Kaunseling: Satu Kajian di Pusat Kaunseling Majlis Agama Islam Negeri Sembilan (PK MAINS)," Islamiyyat 32 (2010): 52.

Siti Zaleha Ibrahim, Nur Sarah Tajul Urus dan Mohd Faisal Mohamed. "Pertukaran Agama dan Kesannya Terhadap Komuniti: Satu Sorotan Terhadap Kes-Kes Murtad dan Masuk Islam di Malaysia," Jurnal Sains Sosial dan Kemanusiaan 3 (2016): 212.

Tuan Sakaria Samela. "Tadbir Urus Saudara Baru: Antara Santunan dan Terpaksa." Kursus Tadbir Urus Saudara Baru. 
Dewan Hadhari, Jabatan Agama Islam Wilayah Persekutuan (JAWI), 26-27 November 2016.

Zainab Ismail. Norabidah Pozi dan Wan Ibrahim Wan Ahmad. "Tahap Pengetahuan Agama Saudara Baru di Pusat Bimbingan Islam Saudara Baru Sultan Abdul Halim Mu'adzam Shah, Kedah Darul Aman," dalam Isu-Isu Pengurusan Saudara Muslim, ed. Razaleigh Muhamat @ Kawangit. Bangi: Penerbit Universiti Kebangsaan Malaysia, 2015.

Zaini Nasohah, Abdel Wadoud Moustafa Moursi Elseodi dan Mohd Izhar Ariff Mohd Kashim. "Status Agama Anak Bagi Ibubapa yang Memeluk Agama Islam di Malaysia," Jurnal Syariah (2010): 440-447.

Zakaria Noh. "Peranan Pertubuhan Kebajikan Islam Malaysia (PERKIM) dalam Pembinaan Keagamaan Mualaf di Malaysia.” Tesis kedoktoran, Universitas Islam Negeri Sultan Syarif Kasim Riau, 2010), 29.

Zanariah Dimon dan Zaini Yusnita Mat Jusoh. "Pengesahan Status Agama di Mahkamah Syariah: Satu Sorotan." Prosiding Persidangan Penyelidikan dan Inovasi Antarabangsa Pertama 2014 (INSAN2014), Kuala Lumpur, 17-18 November 2014.

\section{Temu bual}

Abdul Halim Lim Abdul Rahman (Ketua Unit Dakwah Saudara Kita, Majlis Agama Islam dan Adat Melayu Terengganu) dalam temu bual dengan penulis, 4 Disember 2016.

Abdul Khalid Ahmad (Pegawai Islamic Outreach ABIM Center Kelantan) dalam temu bual dengan penulis, 7 Ogos 2017.

Adibah Haji Mohamad Rifaie (Penolong Pengarah Kanan, Bahagian Dakwah, Jabatan Agama Islam Perak) dalam temu bual dengan penulis, 22 Disember 2016.

Ahmad Taufik Hamdan (Penolong Pegawai Hal Ehwal Islam, Jabatan Hal Ehwal Agama Islam Negeri Sembilan) dalam temu bual dengan penulis, 30 November 2016.

Aisah Ohdin (Penyelia Unit Ukhuwah, Bahagian Dakwah, Jabatan Hal Ehwal Agama Islam Negeri Sabah) dalam temu bual dengan penulis, 11 Januari 2017.

Fakhrurrazi Md Mahathir (Pendaftar Mualaf Negeri Perlis) dalam temu bual dengan penulis, 28 Disember 2016. 
Johari Abdullah (Pengerusi, MACMA Kelantan) dalam temu bual dengan penulis, 7 Ogos 2017.

Madihi Jamali (Ketua Unit Kemajuan Saudara Kita, Bahagian Dakwah, Jabatan Agama Islam Sarawak) dalam temu bual dengan penulis, 10 Januari 2017.

Mohd Leow Abdullah (Penolong Setiausaha, Bahagian Balai Islam Majlis Agama Islam Melaka) dalam temu bual dengan penulis, 14 Disember 2016.

Mohd. Fauzi Bachok (Penolong Pengarah, Unit Ukhuwah, Bahagian Dakwah, Jabatan Agama Islam Negeri Johor) dalam temu bual dengan penulis, 5 Januari 2017.

Rosmadi Ramli (Penolong Pengarah, Unit Dakwah dan Ukhuwah, Bahagian Dakwah, Jabatan Hal Ehwal Agama Islam Kelantan) dalam temu bual dengan penulis, 3 Ogos 2017.

Suhaimi Ismail (Pengurus, Bahagian Pembagunan Muallaf Majlis Agama Islam Selangor) dalam temu bual dengan penulis, 29 November 2016.

Taufik Tee Abdullah (Pegawai Jabatan Hal Ehwal Agama Islam Kelantan) dalam temu bual dengan penulis, 3 Ogos 2017.

Tuan Sheikh Mohd Naim Hj Ahmad (Pengarah, Bahagian Dakwah, Jabatan Agama Islam Kedah) dalam temu bual dengan penulis, 17 Januari 2017. 